\title{
The Japanese island arc and the subduction
}

\section{process}

The western Pacific subduction zones, including the Japanese island arc, in general have contrasting characteristics to those of the eastern $\mathrm{Pa}$ cific counterparts. The Japanese arc itself consists of two arc systems: the east Japan arcs and the west Japan arcs that also have contrasting features. Some results of recent investigations on the tectonics and deeper structures of these subduction zones are reviewed.

\section{Comparative subductology and general features of the Japanese subduction zone}

The Japanese subduction zone forms an important part of the chain of subduction zones in the western Pacific margin. The other major system of subduction zones is the Peru-Chile system along the eastern rim of the Pacific. Subduction zones of these two systems generally have major contrasting characteristics. Typically, the western Pacific subduction zones form island ares with backarc basins, whereas the eastern Pacific ones form continental arcs with Cordilleran mountain ranges in their backarc regions. The end members of these subduction zones are called, in terms of comparative subductology (Uyeda and Kanamori, 1979; Uyeda, 1982, 1983), the Mariana type, where backarc spreading is in action, and the Chileantype, where the backarc is under a compressional stress regime. Major features characteristic to these two types of subduction zones are summarized in figure 1.

The fundamental cause that gives rise to the contrasting features depicted in figure 1 is the difference in the degree of physical coupling between subducting and overriding plates; the coupling is strong in the Chilean-type and weak in the Mariana-type subduction zones. It is not quite clear what causes the different degrees of physical coupling, although several possibilities have been put forward, including the difference in age of subducting plates, convergence rate, motion of overriding plate relative to trench axis, direction of sublithospheric flow, and the physical nature of plate interface, such as asperity (Kanamori, 1986). Recently, Shimamoto and others (1991) have shown that there is a close correlation between the size of maximum interplate earthquakes and the width of that part of the contact plane that is estimated to be seismogenic from thermal and rheological features.

The Japanese subduction zones, in this paper. cover the region extending from the Kuriles in the north to the Philippine Sea in the south (fig. 2). They are subdivided into the following two systems: the east Japan arcs that comprise Kurile, northeastern Honshu, IzuBonin, and Mariana subduction zones; and the west Japan arcs, comprising southwestern Honshu and Ryukyu subduction zones. Along the former system. old Pacific plate is subducting beneath the
$A$

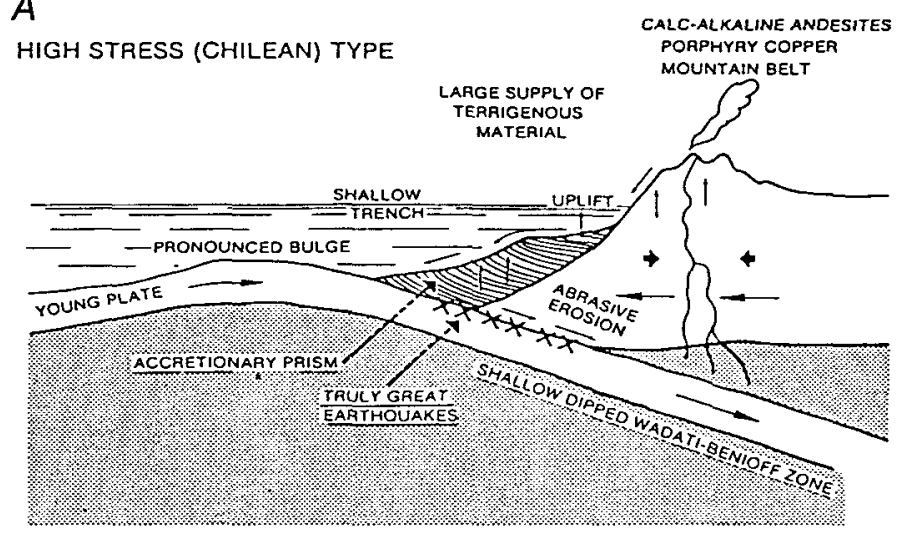

$B$

LOW STRESS (MARIANA) TYPE

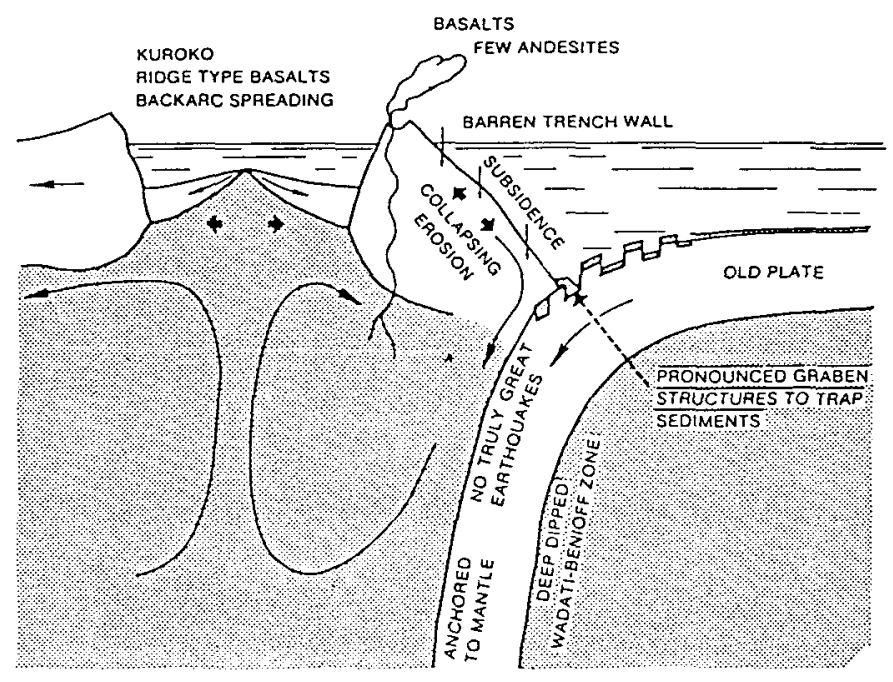

Figure 1.-Cartoon diagrams showing the two ideal modes of subduction with possible tectonic implications and causes (not to scale).

Eurasian plate in the northern portion and beneath the Philippine Sea plate in the southern portion. There is a view that this part of the Eurasian plate joined the North American plate a couple of million or so years ago when collision in Hokkaido caused a jump of the convergent plate boundary between the North American and Eurasian plates from central Hokkaido to the line along the eastern rim of the Sea of Japan and the Itoigawa-Shizuoka Tectonic Line (ISTL) in central Honshu as shown in figure 2 (Nakamura, 1983). This view explains the occurrence of a series of thrust-type earthquakes along the eastern rim of the Sea of Japan and proposes an interesting possibility that the Sea of Japan coast of northeast Honshu is in the 


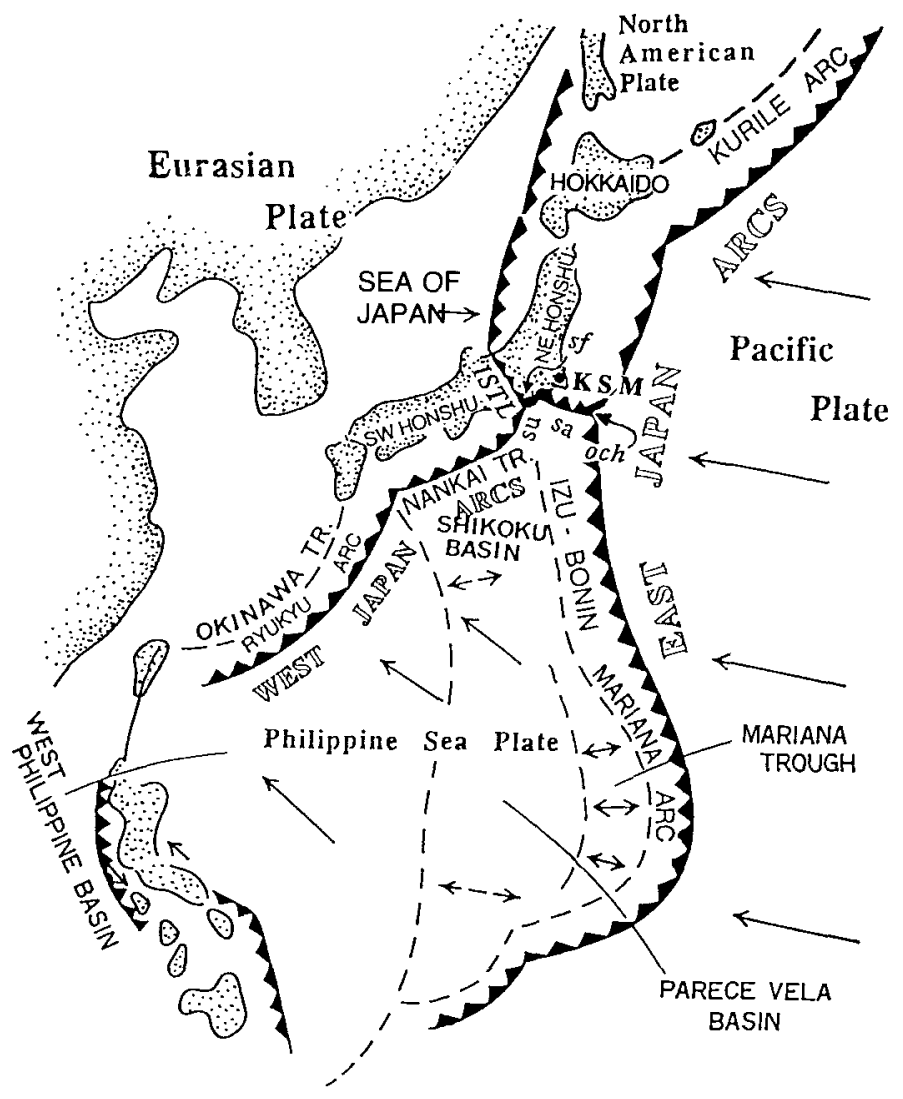

Figure 2.-Outline index map of the Japanese subduction zones. Thick lines with teeth are converging plate boundaries. Arrows indicate relative plate motions. su, Suruga trough; sa, Sagami trough; sf, South Fossa Magna triple junction; och, Off Central Honshu triple junction; ISTL, Itoigawa-Shizuoka Tectonic Line; KSM, Kashima VLBI station.

incipient stage of slow eastward subduction. This view also provides a logical reason why the ISTL became a major thrust boundary and a rapid uplift of the so-called Japan Alps mountains started in early Pleistocene time. Plate boundaries shown in figure 2 are based on this view.

Recent results of very long baseline interferometry (VLBI) measurement, one of the major studies of the Japanese Dynamics and Evolution of the Lithosphere Project (DELP), show that since 1984 Kashima station (KSM in fig. 2), on the North American plate, has been moving away at about $1.4 \mathrm{~cm} / \mathrm{yr}$ from the stations on the stable North American craton. This apparent discrepancy with the rigidplate concept has been interpreted to be a result of intraplate contraction of northeast Honshu (Heki and others, 1989). Together with the wider use of global positioning satellite (GPS) and other space geodetic techniques, such observations will open a new horizon in the study of present-day tectonics.

Along the west Japan arc system of subduction zones, the Philippine Sea plate is subducting beneath the North American plate highly obliquely at the Sagami trough (sa in fig. 2) and the Eurasian plate at the Nankai trough, forming a triple junction (sf) in the South Fossa Magna region (see fig. 6 also for some locations). This triple junction can hardly be called a typical trench-trench-trench (T-T-T) type, as none of the plate boundaries concerned are typical trenches. Both the Sagami trough (sa) and the Suruga trough (su, the eastern end portion of the Nankai trough) land near the supposed triple junction owing to the colliding unsubductable Izu Peninsula, while the ISTL is essentially a thrust fault along the western rim of the Fossa Magna.

Another T-T-T-type triple junction. the Off Central Honshu triple junction (och in fig. 2), which is a classic example (McKenzie and Morgan, 1969) and unique in the present-day globe, is formed to the east of the Kanto area. This triple junction is unstable in the sense of McKenzie and Morgan (1969) and would be stabilized if it migrated westward to the Suruga trough. If the present configuration is to be maintained, the southeastern tip of the overriding "North American" plate will be continuously destroyed. Even if such tec. tonic erosion takes place, the position of the triple junction will still move westward, unless there is sufficient plate production in the northern portion of the retreating Philippine Sea plate (for example. Carlson and Mortera-Gutierrez, 1990). According to the intense investigation of the Kaiko Project, the morphology of the area, as well as the history of the Philippine Sea plate motion, is highly complex, and conflicting views have been expressed on the tectonic evolution of this triple junction (for example, Seno and others, 1989: Houchon and Labaume, 1989). Furthermore, the thickness of subducted Pacific and Philippine Sea plate material intercalating beneath the area complicates the tectonic evolution of the area (Le Pichon and Houchon, 1987). Further west, the Philippine Sea plate is subducting beneath the Eurasian plate at the Nankai trough and the Ryukyu trench.

\section{Comparison of the east and west Japan arcs}

The subduction zones of the east Japan arcs tend to show distinct features that are considered to be inherent to the typical trencharc-backarc setting. For example, figure 3 shows some east-west cross sections of the northeast Honshu arc at about $40^{\circ} \mathrm{N}$. Features to be noted include the Japan Trench and its pronounced negative free-air gravity anomaly, the Japan backarc basin and its negligibly small gravity anomaly and an oceanic crust, the almost-continental crust of the northeast Honshu arc that has anomalously low Pn velocity, the low heat flow on the trench side and the high heat flow on the backarc side, a well-defined front of active volcanoes, the intense interplate thrust seismicity, and a landward-dipping highV-high-Q lithospheric slab having deep seismicity and forming a double Wadati-Benioff zone. Recently, electromagnetic study (for example, Utada, 1987) has revealed some details of the subterranean distribution of electrical conductivity that show that the subducting slab is topped by a highly conducting oceanic crust and that the volcanic zone is underlain by a conducting lower crust. Despite the high heat flow, the Sea of Japan area shows no high conducting layer.

One of the basic problems is how to generate arc volcanism where cold lithospheric plate subducts. Tatsumi (1990) made an interesting suggestion that fluid-phase material driven off from the slab at shallower depth produces hydrated peridotites that are dragged down by the slab to greater depths to provide $\mathrm{H}_{2} \mathrm{O}$ for generation of primary magmas under the volcanic zone.

Recent seismic tomographic investigations, which use the seismic networks developed in the region under the National Earthquake Prediction Program, have revealed some remarkable details of the crust and upper mantle structure of Honshu. It has been observed that low velocity patches exist in the crust and the uppermost mantle. most probably corresponding to the distribution of subterranean magmas (Zhao, 1990). 
Figure 3. - East-west geophysical cross sections of northeast Honshu arc at $40^{\circ}$ $N$. For the data sources of $A-E$, see Uyeda (1982). F is after Utada (1987). Electrical conductivity in $\mathrm{s} / \mathrm{m}$.

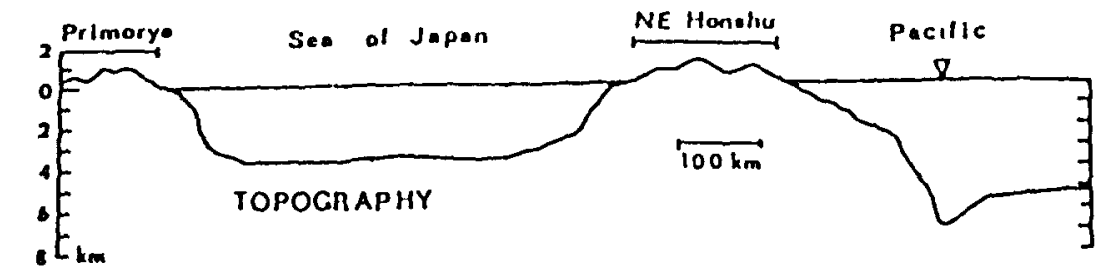

A

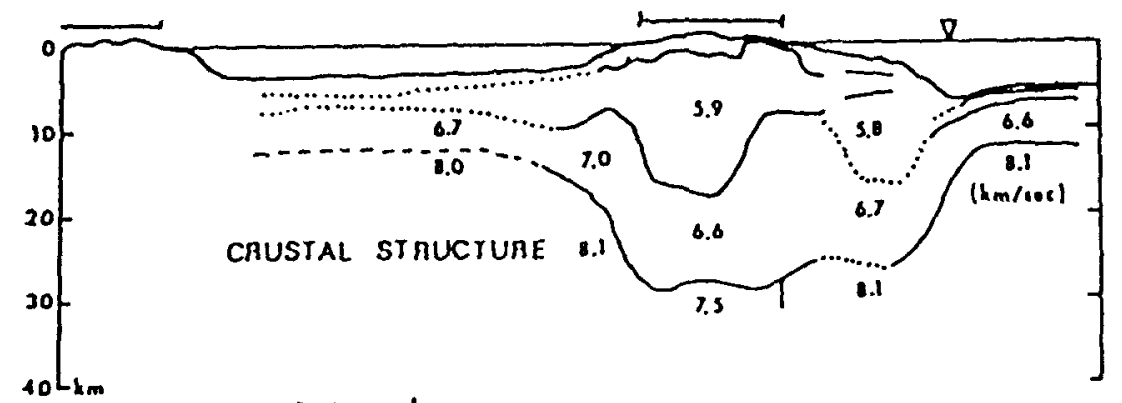

$B$

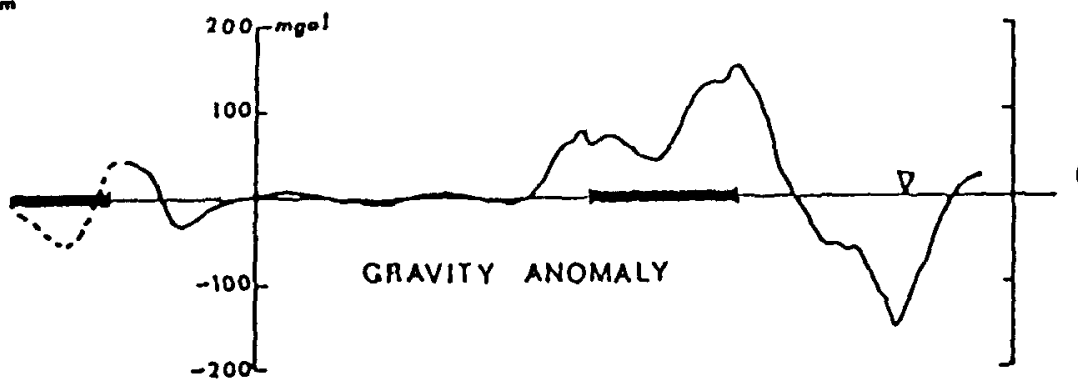

c
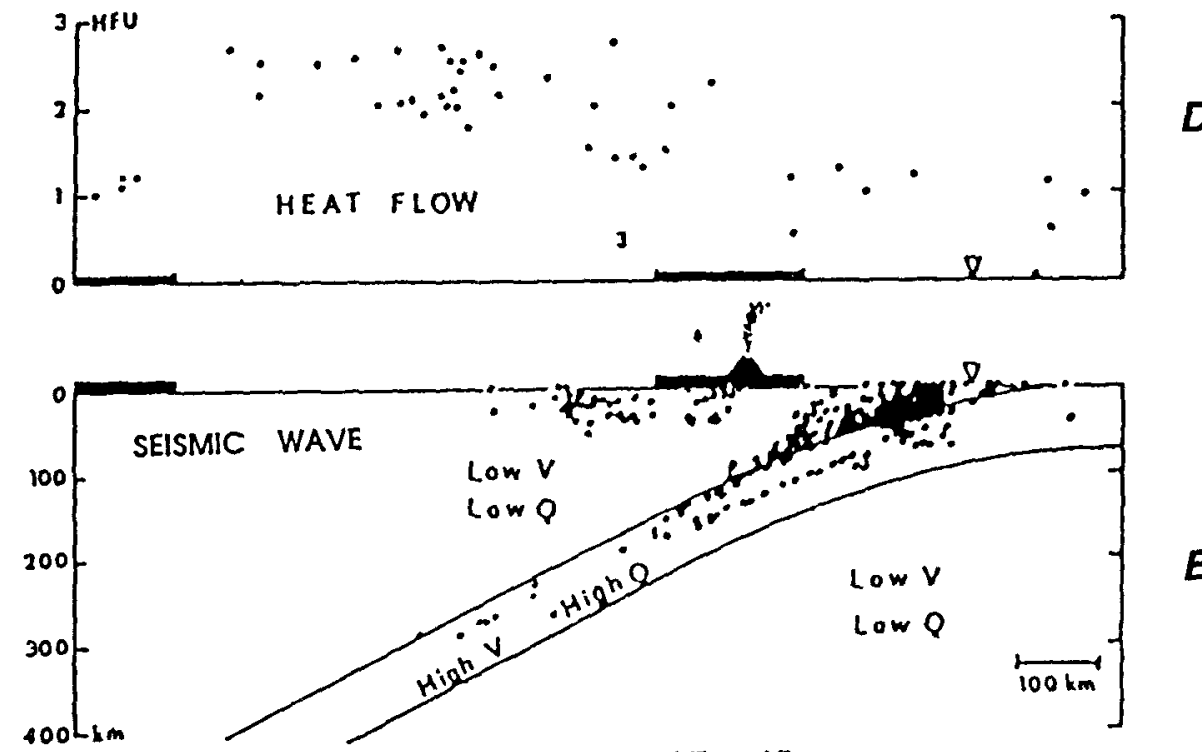

$E$

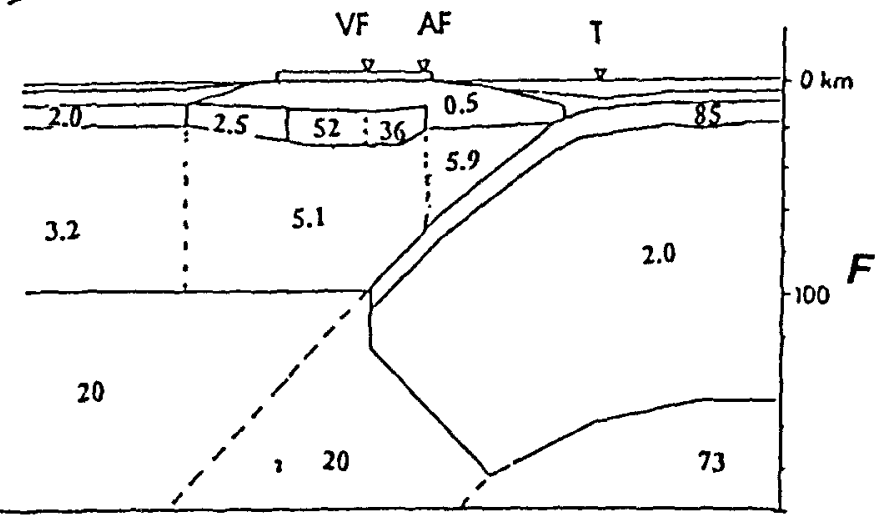

September 1991 


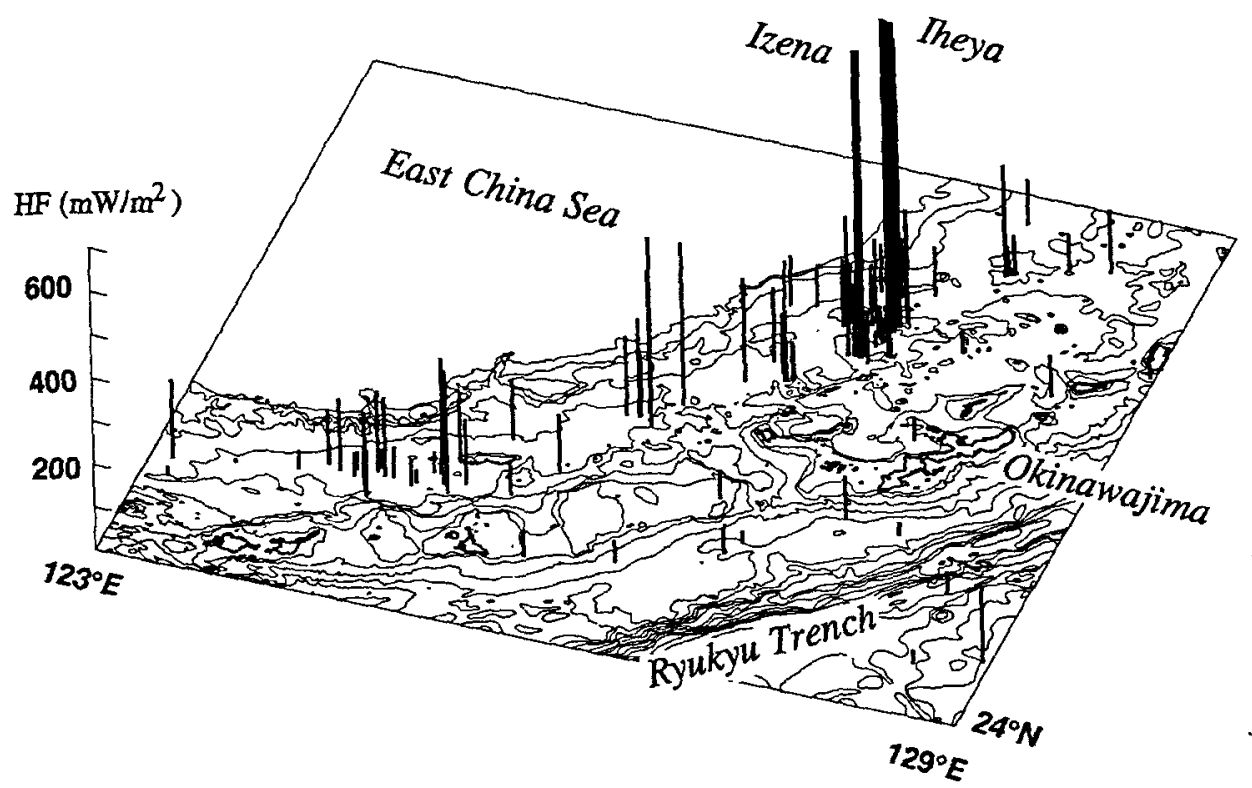

Figure 4. - Bird's eye representation of observed heat flow values in the Ryukyu arc and Okinawa trough region (Kinoshita and others, in preparation). Iheya and Izena are two areas with hydrothermal activity. Heat flow values are truncated at $700 \mathrm{~mW} / \mathrm{m}$.

Although not shown in figure 3 , the source mechanism of crustal earthquakes and orientation of Quaternary dikes indicate that thecrustal stress under the arc and backarc region is compressional to shear (for example, Nakamura and Uyeda, 1980). The landward wall of the Japan Trench shows essentially erosional features (for example, Von Huene and Culotta, 1989) with only a little sediment accretion, which possibly indicates that, until the relatively recent past, sediment subduction and trench-wall erosion, rather than sediment accretion, were occurring (Uyeda, 1982). Because the present Sea of Japan is an inactive backarc basin with a compressional stress regime, the northeast Honshu subduction zone today belongs to the Chilean ,type.

Also, recently Fukao and others (1991) made a deep tomographic inversion using ISC first arrival data for the western Pacific. $A$ cross section of the northeast Honshu arc indicates that a slab-like high velocity zone dips down along the Wadati-Benioff zone and bends to subhorizontal to lie above the $670-\mathrm{km}$ discontinuity. The subhorizontal portion apparently thickens vertically to penetrate into the deep mantle; this provides an interesting clue to the fate of the subducted slab.

South of the Off Central Honshu triple junction, the subduction zones are more of the Mariana type-the Marianas are their end member. These arcs are less continental, less seismic, and the stress in backarc, are, and forearc regions tends to be tensional. Although the Bonin trough is considered to be an aborted rift (Katao and others, 1990), there is a series of backarc depressions along the Bonin arc where extensional tectonics is in action (Honza and Tamaki, 1985). The Mariana backarc trough is actively spreading, as inferred earlier by Karig (1971) and verified by the Deep Sea Drilling Project (Hussong and Uyeda, 1981). Extremely high heat flow and spectacular hydrothermal activities (for example, Hobart and others, 1983: Hawkins and others, 1990), among many other indications, amply support this. On the landward wall of the Bonin and Mariana trenches, there is no accretion of sediments on the subducting plate, but rocks are observed that represent the basement of the arc and entrapped or obducted sea floor (Johnson and Fryer, 1991).

In contrast, subduction zones of the west Japan arcs are less typical. The Ryukyu arc, for example, has active volcanoes only in its northern part, and the Wadati-Benioff zone reaches only to about $100-\mathrm{km}$ depth. This arc belongs to the Mariana type in the sense that its backarc region is under extensional stress and the Okinawa trough is likely a nascent backarc spreading basin (Kimura and others, 1986: Sibuet and others, 1987). Extremely high heat flow (Yamano and others, 1989; Kinoshita and others, 1990) and hydrothermal mounds and smokers having sulfide mineralization (Kimura and others, 1988; Halbach and others, 1989) strongly support this possibility (fig. 4). However, the crustal structure of the Okinawa trough is not typically oceanic, rather it is like an extended continental structure (Nagumo and others, 1986). The Ryukyu arc, which was one of the major targets of the DELP because it is an atypical Mariana type, appears to provide a unique opportunity to study the rifting stage of a continental margin.

Even more atypical is the southwest Honshu arc, although this arc shows remarkable zonal geologic structures that have developed through a long history of accretion caused by subduction (for example, Taira and Tashiro, 1987). The Nankai trough (trench) is now forming an enormous accretionary prism with interesting signatures of fluid seepage possibly through the décollement (Henry and others. 1989: Yamano and others, 1991). However. the Cenozoic volcanism of this arc is quite anomalous for arc volcanism (Iwamori, 1991), and there is no present chain of volcanoes. Heat flow also has an atypical distribution (Yamano and others, 1984): there is high heat flow in the Nankai trough and no regionally high heat flow on the arc. The shape of the ill-defined Wadati-Benioff zone is quite distorted and traced only to no more than $100-\mathrm{km}$ depth as shown in figure $5 B$ (Mizoue and others, 1983). These features may be related to the fact that the relatively slowly $(4 \mathrm{~cm} / \mathrm{yr})$ subducting Shikoku basin lithosphere is quite young (20-15 m.y. old) and the Nankai trough is under an unusually massive supply of sediments from the rapidly uplifting South Fossa Magna collision zone in the east (Nitsuma, 1989). The southwest Honshu arc is an atypical Chilean-type arc.

\section{Central Japan where northeast and southwest Honshu arcs meet and the Izu-Bonin arc collides with Honshu}

Under the Kanto-Tokai district (fig. 6), where the northeast and southwest Honshu arcs meet, the geometry and relative motion of subducting Pacific and Philippine Sea plates is complicated. On the 
basis of recent high-density seismic data, including hypocentral distribution, velocity. structure, and focal mechanism, some remarkable details have now been obtained (for example. Ishida, 1991). As an example, figures $5 A$ and $B$ show the upper surface and the direction of motion relative to the Eurasian plate of the Pacific and Philippine Sea plates. It may be noted that the shape of the Philippine Sea slab cannot be determined under the volcanic belt in the north of Izu Peninsula because that portion of the slab is aseismic. Probably that portion of the slab, because it is under the volcanic axis of the colliding arc, is too hot to be seismic.

The South Fossa Magna collision, which caused the major bend of the geologic structures of southwest Honshu (fig. 6) and the rapid uplift of the region, has also been a major target of the DELP. The collisional process has been documented for at least two consecutive events, one collision of the Tanzawa block in the late Miocene to Pliocene and the other of the Izu block in the early Pleistocene to the present (for example, Niitsuma, 1989). The area of the Suruga trough in the Tokai region constitutes a major gap in large interplate earthquakes along the Japanese subduction zones and an M 8 class earthquake is expected to occur in the near future (for example, Ishibashi, 1981). The present author. however, holds some doubt on this large expected magnitude because the area is close to a collision boundary, which seldom generates truly great earthquakes (Kelleher and Mc-

Figure 5. $-A$, Depth contours of the Wadati-Benioff zone showing subduction of the Pacific plate (Ishida, 1991). Triangles are active volcanoes. $B$, Depth contours of the Wadati-Benioff zone showing subduction of the Philippine Sea plate (Ishaida, 1991, and Mizoue and others, 1983). In both figures, large white arrows indicate the converging plate motions of the Pacific and Philippine Sea plates.

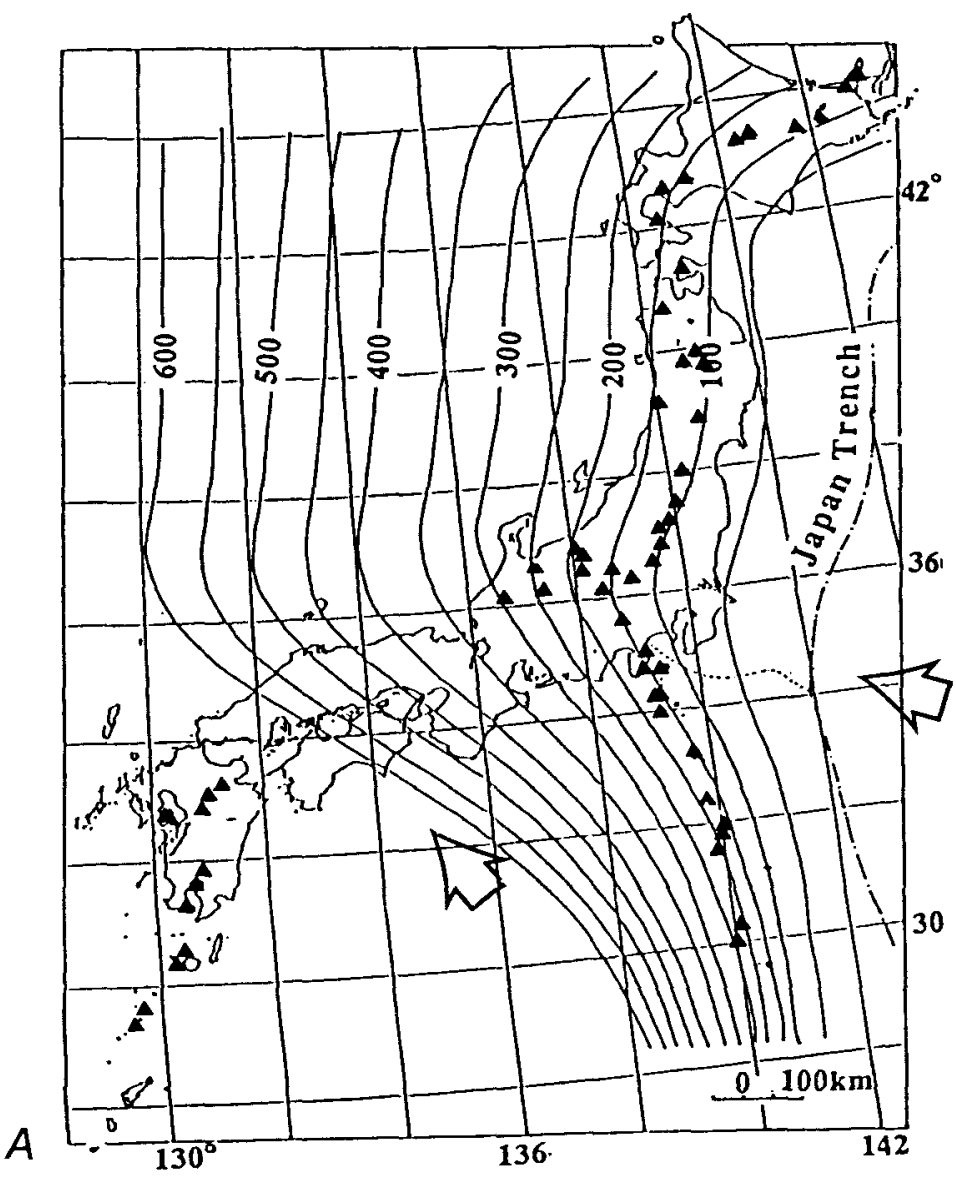

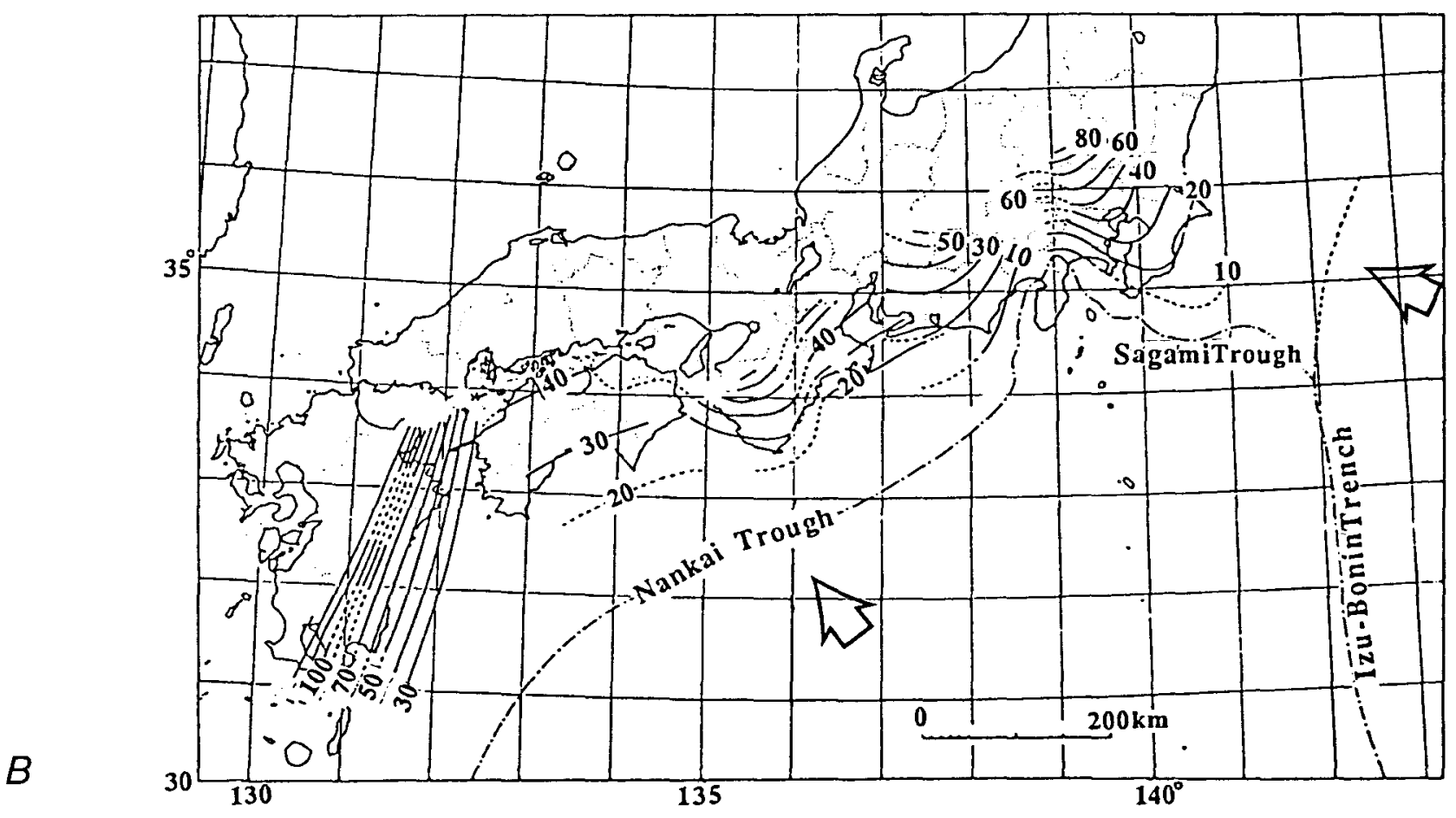




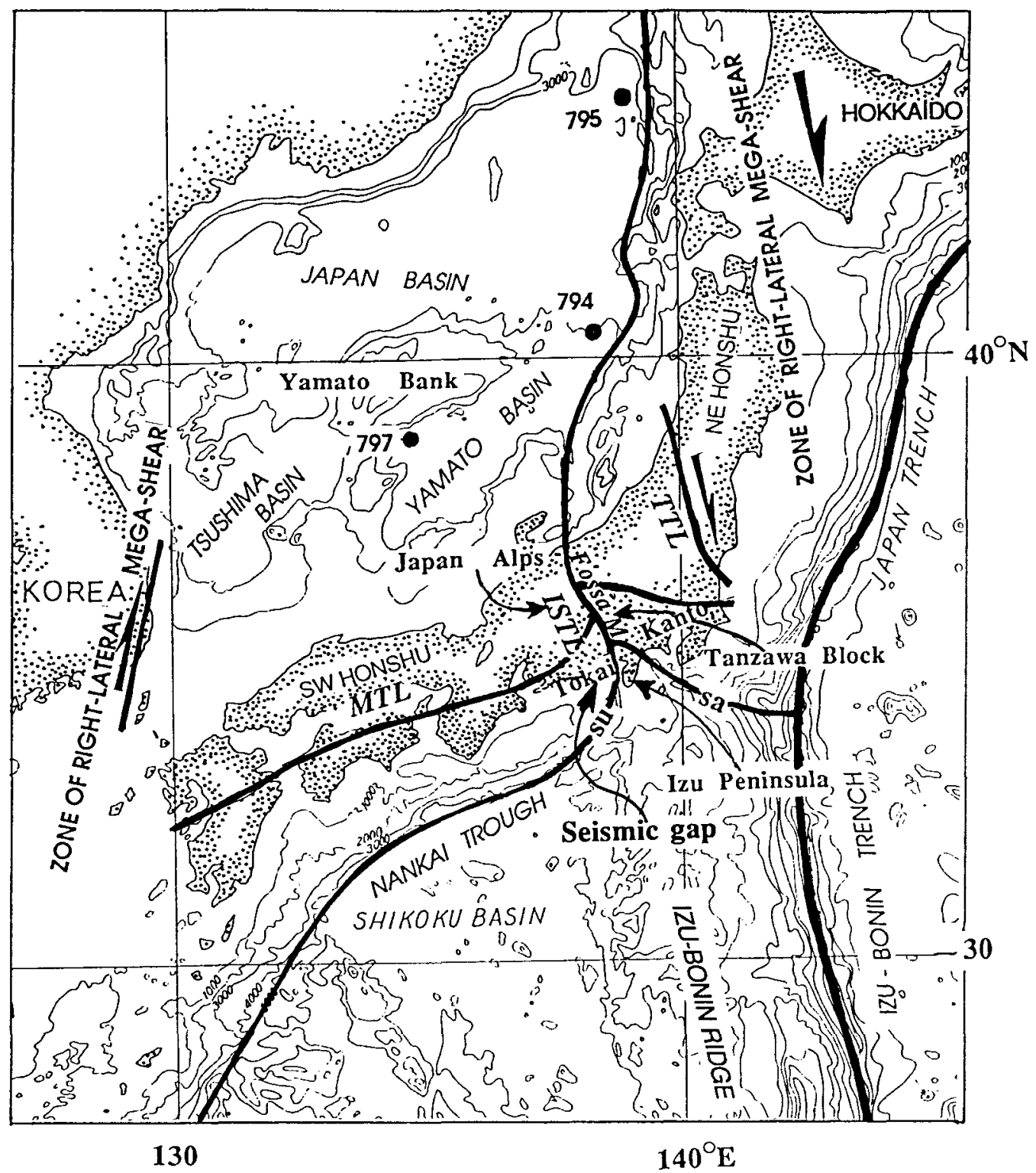

Figure 6. -An index map of the Japan area. TTL,Tanakura Tectonic Line; ISTL, Itoigawa-Shizuoka Tectonic Line; Fossa M, Fossa Magna: MTL, Median Tectonic Line; su, Suruga trough; sa, Segami trough; 794, 795, 797, Ocean Drilling Program (ODP) sites where basement rocks have been recovered. Zones of right-lateral megashear are supposed to have been active during the opening of the Sea of Japan according to Jolivet and others (1991).

Cann, 1976); moreover, although the area in question is inthe forearc region of the Suruga trough, it is close to the volcanic zone associated with the Pacific subduction.

It is now believed that the boundary between the northeast and southwest Honshu arcs is the Tanakura Tectonic Line (TTL in fig. 6) as the zonal structures of southwest Honshu along the Median Tectonic Line (MTL in fig. 6) can be traced to this line. This tectonic line (TTL) is a major shear zone that has separated northeast Japan and southwest Japan since pre-Miocene time and might have played, together with other similar faults, an important role in accommodating the displacements between southwest Honshu and northeast Honshu during the Miocene opening of the Sea of Japan. Since the opening of the Sea of Japan, the TTL has been inactive, and at present. the boundary of the northeast and southwest Honshu ares is considered the Fossa Magna and. more precisely, the ISTL. Then. what is the Fossa Magna?

The Fossa Magna is a zone of late Cenozoic subsidence that has a thick sequence of sediments and that cuts across central Honshu. The sediments were folded and uplifted during the Pleistocene. Its western rim, the ISTL, has also been a major thrust with a strike-slip component, and the region directly west of it has been rapidly uplifting and formed the Japan Alps mountain range during the Pleistocene. The Fossa Magna has long been noted as one of the most important tectonic features of Japan. Despite an enormous amount of investigation, however, the origin of this gigantic rift that turned into uplift has been an enigma. Recently, a suggestion has been put 
forward that the Fossa Magna may be an aulacogen associated with the opening of the Sea of Japan (Shiki and Tateishi, 1991). According to these authors, at the nascent stage of the opening of the Sea of Japan, a three-armed rift was formed, as in the model of Burke and Dewey (1973), and the arm that now forms the Fossa Magna ended up as a failed rift (fig. 7), which then was subject to compressional stress from the subduction of the Pacific plate. It is an interesting idea. The present author might add that the real compression could have been precipitated by the jump of the converging North American and Eurasian plate boundary to the ISTL, as mentioned in the preceding section.

\section{Opening of the Sea of Japan}

The Sea of Japan comprises three major basins, the Japan Basin, Yamato Basin, and Tsushima Basin with the continental Yamato Bank in the middle (fig. 6). At least the Japan Basin has a normal oceanic crust and is believed to be of a backarc spreading origin. The age of the basin, however, has not been clear, as the magnetic lineation patterns so far studied are not convincingly distinct for dating (Isezaki, 1986). Heat-flow and basement-depth data suggest an age of $30-15 \mathrm{Ma}$, based on the standard plate-cooling model, whereas the paleomagnetic study claims that double-door-type rotation of the northeast and southwest Honshu arcs took place at about 21-14 Ma and $15 \mathrm{Ma}$, respectively (within almost a 1-m.y. period) (Otofuji and others, 1985). Recent ODP drilling at sites 794, 795, and 797 (fig. 6) reached hard basaltic rock with an age of $25 \mathrm{Ma}$.

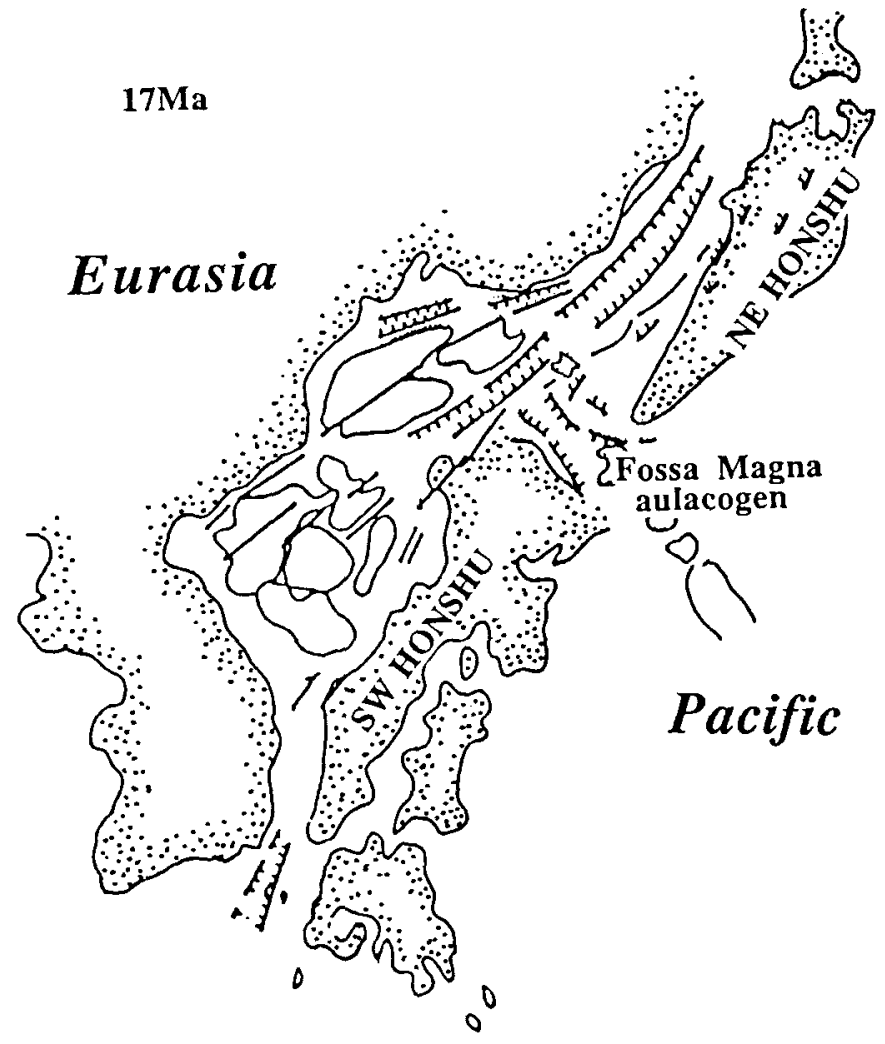

Figure 7. - An explanatory reconstruction (17 Ma) map of the Sea of Japan area for the possible aulacogen origin of the Fossa Magna (after Shiki and Tateishi, 1991).
This would provide the minimum age since it was not certain whether the rock reached was the real basement or not (Leg 127 and Leg 128 shipboard scientific parties, 1990).

As to the mode of opening, the paleomagnetic data of the differential rotations of the northeast and southwest Honshu arcs has imposed a severe constraint on subsequent reconstruction models (for example, Otofuji and others, 1985; Niitsuma and others, 1988). Any model that takes the paleomagnetic data at its face value that the southwest Honshu arc rotated some 50 degrees as a single rigid body in such a short time as $1 \mathrm{~m} . \mathrm{y}$. would require an impossibly high rate of displacement at its tip; the eastern end of southwest Honshu had to move with some $600-\mathrm{mm} / \mathrm{yr}$ speed. Lallemand and Jolivet (1985/86) and Jolivet and others (1991) have put forward alternative pull-apart basin models on the basis of onland and offshore structural data on right-lateral megashear zones on both the west and east sides of the Sea of Japan. These models appear reasonable, but are apparently incompatible with the paleomagnetic data, because the expected rotation of the arc according to the authors of these models is only 20 degrees or less. Kanaori and others (1990), on the other hand, have shown that considerable block rotations, similar to those suggested by Nur and others (1986), have accompanied fault movements in central Honshu even in the Quaternary Period (fig. 8), and they pointed out that a substantial part of paleomagnetically proposed rotations, during the opening of the Sea of Japan, may be accounted for by similar rotations of crustal blocks between faults. This seems to be a very pertinent point. At any rate, the simplistic doubledoor-type rotation model should be reexamined in the light of structural geology.

What then was the driving mechanism of these surface tectonics that produced the Sea of Japan? This pertains to the very fundamental question of comparative subductology. The present author favored a model that assumed that the subducted slab was anchored to the asthenosphere and, if the latter was stationary, that backarc spreading was possible when the overriding plate retreats landward, as is actually happening in the Philippine Sea. When applied to the case of the Sea of Japan, however, it did not work too well (Kimura and Tamaki, 1986), which suggests that a seaward retreat of trench may be necessary. In contrast to these passive spreading models, there are active spreading models also. For example, Tatsumi and others (1990) proposed that the spreading of the Sea of Japan was caused by an asthenospheric injection into the upper mantle under the area in Oligocene time. Their argument was based on the geologic record of a sudden seaward shift of the volcanic front of northeast Honshu, which was interpreted to be a result of the asthenospheric injection and subsequent steepening of the subducted slab. This course of events was considered to have triggered the seaward retreat of the trench needed for the opening of the Sea of Japan. An even more active mechanism is that in which a hypothetical upper mantle migrating hot region, which has no relationship with subduction, produced the series of the western Pacific's new basins (Miyashiro, 1986). The issue here is somewhat analogous to the debate on whether such processes as sea-floor spreading and hotspot activity are passive or active, and this discussion will continue for some time into the future.

\section{Concluding remarks}

During the last several years, there have been a number of important contributions to the study of tectonics and deeper processes related to subduction in the region of the Japanese subduction zones. A substantial part of these contributions has come from such Japanese national programs as the Japanese DELP, the National Earthquake Prediction Program, and the "Shinkai 2000" Diving Programs. 


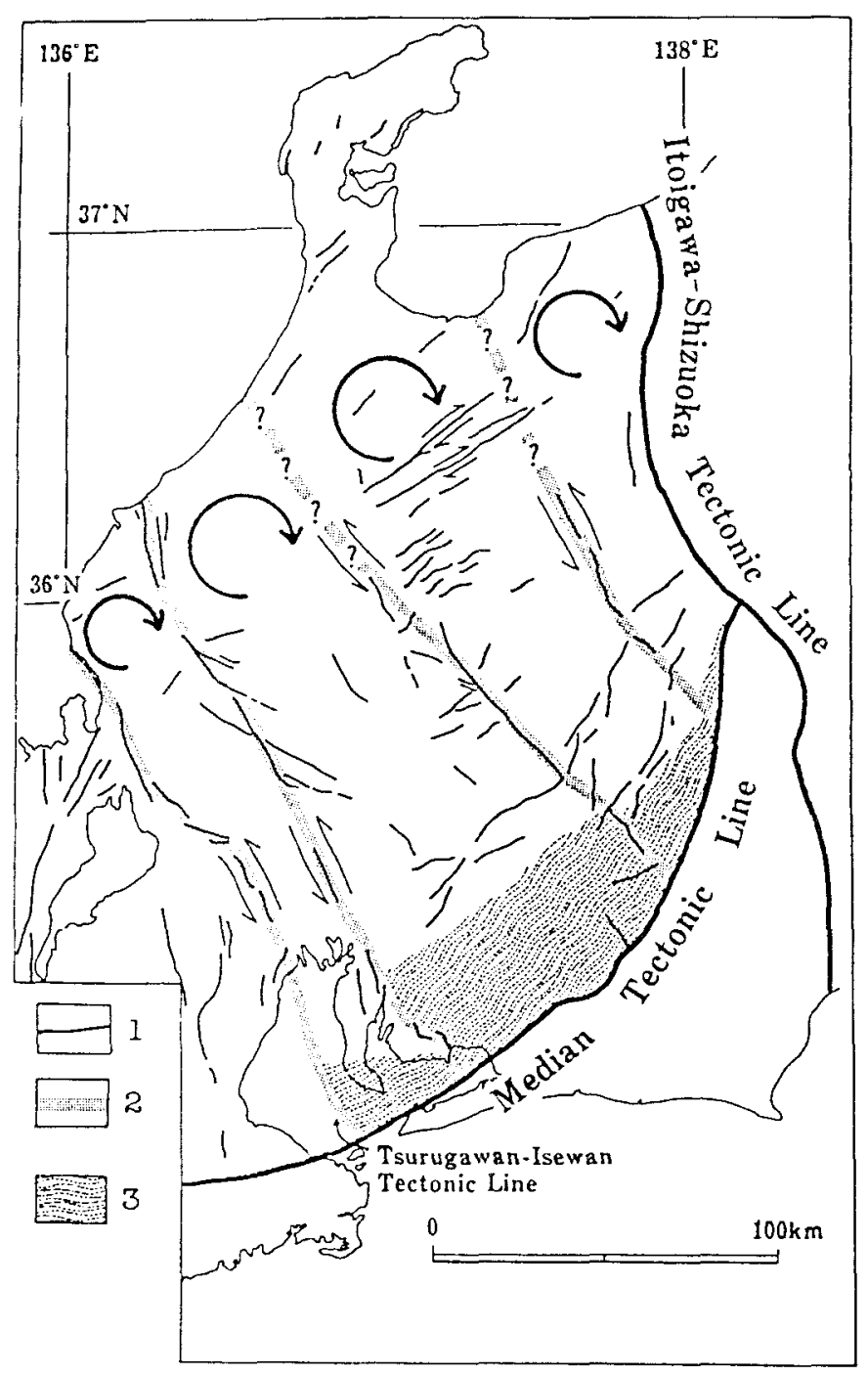

Figure 8. - Block structure of central Honshu (Kanaori and others, 1990). 1, active fault; 2, block boundary; 3, block termination gaps.

Important contributions have also come out of such international cooperative programs as the Franco-Japanese Kaiko Project, the Ocean Drilling Prohtsm, the US-Japan Izu-Bonin-Mariana Alvin Dive Project, and the German-Japanese Okinawa Trough Project. It is encouraging that some cooperative projects involving USSR and China are already underway, and many more are expected in coming years. An obvious characteristic of the recent investigation is the use of new technologies. VLBI, seismic tomographic techniques, precise positioning systems, high-tech acoustic survey tools, deep-sea drilling. deep submersibles, and long-term ocean-bottom instruments are just a few examples. There is no doubt that future work that makes use of these new technologies will need more international cooperation.

\section{References}

Burke, K., and Dewey, J.F., 1973, Plume-generated triple junctions-Key indicators in applying plate tectonics to old rocks: Journal of Geology, v. 81, p. $406-433$.
Carlson, R.L.. and Mortera-Gutierrez. C.A.. 1990. Subduction hinge migration along the 1zu-Bonin-Mariana arc: Tectonophysics, v. Is! no. $1-4$, p. $331-344$.

Fukao. Y., Nenbai, M., Obayashi, M., and Inoue, H. 1991, Subducting slabs stagnant in the mantle transition zone: written communication.

Halbach, P., Nakamura, K., Wahsner, M.. Lange. J., Sakai, H., Kaseliz, L. Hansen, R.-D. Yamano. M.. Post, J.. Prause, B., Seifert, F Michaelis, W.. Teichmann, F, Kinoshita, M. Marten, A. Ishibasm. J., Czerwinski, S., and Blum, N., 1989. Probable modern analogue :f Kuroko-type massive sulphide deposits in the Okinawa Trough back-ins basin: Nature. v. 338, no. 6215, p. $496-499$.

Hawkins. J.W., Lonsdale, P.F., Macdougall. J.D. and Volpe, A.M 1990. Petrology of the axial ridge of the Mariana Trough backias spreading center: Earth and Planctary Science Letters, \&. 10 t: p. $226-250$.

Heki, K., Takahashi, Y., and Kondo. T. 1989. Contraction of northeastem Japan-Evidence from horizontal displacement of a Japanese station in global very long baseline interferometry networks: Tectonophysic v. 181 , no. $1-4$, p. $113-122$

Henry, P., Lallemant. S.J., Le Pichon, X.. and Lallemand. S.E., 198\%. Fluid venting along Japanese trenches - Tectonic context and thermat modeling: Tectonophysics. v. 160, no. 1-4, p. 277-291.

Hobart, M., Anderson, R.N. Fujii. N., and Uyeda, S.. 1983, Heat flow from hydrothermal mounds in two million year old crust of the Mariana Trough which exceeds two watts per square meter: EOS, v. 64. p. 315

Honza, E., and Tamaki, K., 1985, the Bunin Are, in Nairn, A.E.M Stehli, F.G., and Uyeda, S., eds., The ocean basins and margirs v. 7A, The Pacific Ocean: New York. Plenum Press, p. 459-502.

Huchon, P., and Labaume, P.. 1989, Central Japan triple junction-A thresdimensional compression model: Tectonophysics, v. 160 , no. $1-$ p. $117-133$.

Hussong. D.M., and Uyeda. S.. 1981. Tectonic process and history of the Mariana arc-A synthesis of the results of Deep Sea Drilling Project Leg 60, in Hussong, D.M.. Uyeda, S., and others. Initial reports of the Deep Sea Drilling Project, v. 60: Washington, D.C., U.S. Government Printing Office, p. 909-929.

Isezaki, N., 1986, A geomagnetic anomaly map of the Japan Sea: Journal of Geomagnetism and Geoelectricity, v. 38, p. 403-410.

Ishibashi, K., 1981, Specification of a soon-to-oceur seismic faulting in the Tokai district, central Japan, based upon seismorectonics, in Simpson. D.W., and Richards, P.G., eds., Earthquake prediction--An international review: American Geophysical Union, Maurice Ewing Series 4, p. 297-332.

Ishida, M., 1991, A new interpretation of the geometry and relative motion of the Philippine Sea plate and Pacific plate beneath the Kanto-Tokd District. Japan: Journal of Geophysical Research (in press).

Iwamori, H., 1991, Zonal structure of Cenozoic basalts related to mantie upwelling in southwest Japan: Journal of Geophysical Research, v. 96. no. B4, p. 6157-6170.

Johnson, L.E., and Fryer, P., 1990, The first evidence of MORB-like lavas from the outer Mariana forearc-Geochemistry, petrography and tectonic implications: Earth and Planetary Science Letters, v. 100, p 304-316.

Jolivet, L., Huchon, P., and Brun, J.P.. 1991, Arc deformation anj marginal basin opening-Japan Sea as a case study; Journal ot Geophysical Research, v. 96, no. B3, p. $+367-4384$.

Kanamori, H., 1986, Rupture process of subduction-zone earthquake: Annual Reviews of Earth and Planetary Sciences, v. 14, p. 293-322.

Kanaori, Y., Yairi, K., Kawakami, S., and Takeshita, T., 1990, An anglo of block rotation caused by left-lateral faulting in the Inner Belt if Central Japan-Comments on a rotational value of Southwest Japat inferred from paleomagnetic data: Zisin, v. 47, p. 539-542. [1] Japanese.]

Karig, D.E., 1971, Origin and development of marginal seas in the wester Pacific: Journal of Geophysical Research, v. 76. p. 2542-2561.

Kelleher, J., and McCann. W.R., 1976, Buovant zones, great earthquakes and unstable boundaries of subduction: Journal of Geophysicat Research, v. 81, p. 4885-4896.

Katao, H., Hino, R., Kinoshita, H., and Nagumo, S., 1990, Crustal structure of the Bonin Trough: Tectonophysics, v. 181, no. 1-4 p. $345-350$. 
Kimura, G., and Tamaki, K., 1986, Collision, rotation and back arc spreading, the case of the Okhotsk and Japan seas: Tectonics, v. 5, p. 349-401.

Kimura, M., Kaneoka, I., Kato, Y., Yamamoto, S., Kushiro, I., Tokuyama, H., Kinoshita, H., Isezaki, N., Masaki, N., Oshida, A., Uyeda, S., and Hilde, T.W.C., 1986, Report on DELP 1984 cruises in the middle Okinawa Trough, part V-Topography and geology of the central grabens and their vicinity: Bulletin of the Earthquake Research Institute, v. 61, p. 269-310.

Kimura, M., Uyeda, S., Kato, Y., Tanaka, Y., Yamano, M., Gamo, T., Sakai, H., Kato, S., Izawa, E., and Oomori, T., 1988, Active hydrothermal mounds in the Okinawa Trough backarc basin, Japan: Tectonophysics, v. 145 , no. 3-4, p. 319-324.

Kinoshita, M., Yamano, M., Post, J., and Halbach, P., 1990, Heat flow measurements in the southern and middle Okinawa Trough on $R / V$ Sonne in 1988: Bulletin of the Earthquake Research Institute, v. 65 , p. 571-588.

Lallemand, S., and Jolivet, L., 1985/1986, Japan Sea-A pull-apart basin? Earth and Planetary Science Letters, v. 76, p. 375-389.

Leg 127 and Leg 128 shipboard scientific parties, 1990, Evolution of the Japan Sea: Nature, v, 346, no. 6279, p. 18-20,

Le Pichon, $X$. and Huchon, P., 1987, Central Japan triple junction revisited: Tectonics, v. 6 , no. 1, p. 35-46.

McKenzie, D., and Morgan, J., 1969, Evolution of triple junctions: Nature, v. 224 , p. $125-133$.

Miyashiro, A., 1986, Hot regions and origin of marginal basins in the western Pacific: Tectonophysics, v. 122, no. 3-4, p. 195-216.

Mizoue, M., Nakamura, M., Seto, N., Ishiketa, Y., and Yokota, T., 1983, Three-layer distribution of microearthquakes in relation to focal mechanism variation in the Kii Peninsula, southwestern Honshu, Japan: Bulletin of the Earthquake Research Institute, v. 58, p. 287-310.

Nagumo, S., Kinoshita, H., Kasahara, J., Ouchi, T., Tokuyama, H., Asanuma, S., Koresawa, S., and Akiyoshi, H., 1986, Report on DELP 1984 cruises in the middle of Okinawa Trough-part II, Seismic structural studies: Bulletin of the Earthquake Research Institute, v. 61, p. 167-202.

Nakamura, K, 1983, Possible nascent trench along the eastern Japan sea as the convergent plate boundary between Eurasian and North American plates: Bulletin of the Earthquake Research Institute, v. 58, p. 711-722. [In Japanese.]

Nakamura, K.. and Uyeda, S., 1980, Stress gradient in arc-backarc regions and plate subduction: Journal of Geophysical Research, v, 85, no. B11, p. 6419-6428.

Niitsuma, N., 1989, Collision tectonics in the south Fossa Magna, central Japan: Modern Geology, v. 14, no. 1, p. 3-18.

Niitsuma, N., Saito, Y., and Taira, A., 1988, Reconstruction of the Japanese Islands before Japan Sea opening: Journal of Physics of the Earth, v. 36, p. S133-S142.

Nur, A., Ron, H., and Scotti, O., 1986, Fault mechanics and the kinematics of block rotations: Geology, v. 14, p. 746-749.

Otofuji, Y., Matsuda, T., and Nohda, S., 1985, Opening mode of the Japan Sea inferred from the paleomagnetism of the Japan arc: Nature, v. 317, p. $603-604$.

Seno, T., Ogawa, Y., Tokuyama, H., Nishiyama, E., and Taira, A., 1989. Tectonic evolution of the triple junction off central Honshu for the past 1 million years: Tectonophysics, v. 160, no, 1-4, p. 91-116.

Shiki, T., and Tateishi, M., 1991, On the hypothesis that Fossa Magna is an aulacogen: Earth Monthly, special issue, no, 3, Active Margins, p. $106-112$.

Shimamoto, T., Seno, T., and Uyeda, S., 1991, Rheological framework for comparative subductology, in Aki, K., and Dmowska, R., eds., Interrelation between geophysical structures and processes: American Geophysical Union Geophysical Monograph (in press).

Sibuet, J.-C., Letouzey, J., Barbier, F., Charvet, J., Foucher, J.-P., Hilde, T.W.C., Kimura, M., Chiaco Ling-Yun, Marsset, B., Muller, C., and Stephan, J.-F.. 1987, Back arc extension in the Okinawa Trough: Journal of Geophysical Research, v. 92, no. B13, p. 14041-14063.
Taira, A., and Tashiro, M., 1987, Late Paleozoic and Mesozoic accretion tectonics in Japan and eastern Asia, in Taira, T., and Tashiro, M., eds., Historical biogeography and plate tectonic evolution of Japan and eastern asia: Tokyo, Terra Scientific Publishing Company, p. 1-43.

Tatsumi, Y., 1989, Migration of fluid phases and genesis of basalt magmas in subduction zones: Journal of Geophysical Research, v. 94, no. B4, p. $4697-4707$.

Tatsumi, Y., Maruyama, S., and Nohda, S., 1990, Mechanism of backarc opening in the Japan Sea: Role of asthenospheric injection: Tectonophysics, v. 181 , no. 1-4, p. 299-306.

Utada, H., 1987. A direct inversion method for two-dimensional modeling in the geomagnetic induction problem: University of Tokyo thesis

Uyeda, S., 1982, Subduction zones-An introduction to comparative subductology: Tectonophysics, v. 81, no. 3-4, p. 133-159.

1983. Comparative subductology: Episodes, v, 6, no. 2, p. 19-24.

Uyeda, S., and Kanamori, H., 1979, Back-arc opening and the mode of subduction: Journal of Geophysical Research, v. 84, p. 1049-1061.

zvon Huene, R., and Culotta, R., 1989, Tectonic erosion at the front of the Japan Trench convergent margin: Tectonophysics, v. 160, no. 1-4, p. $75-90$.

Yamano, M., Foucher, J.-P., Kinoshita, M., Fisher, A., Hyndman, R.D., and Leg 131 shipboard scientific party, 1991, Heat flow and fluid flow regime in the western Nankai accretionary prism: written communication.

Yamano, M., Uyeda, S., and Honda, S., 1984, Nankai Trough-A hot trench?: Marine Geophysical Researches, v, 6, p. 187-203.

Yamano, M., Uyeda, S., Foucher, J.-P., and Sibuet, J.-C., 1989, Heat flow anomaly in the middle Okinawa Trough: Tectonophysics, v. 159 , no. 3-4. p. 307-318.

Zhao, D., 1990, A tomographic study of seismic velocity structure in the Japanese islands: Tohoku University thesis.

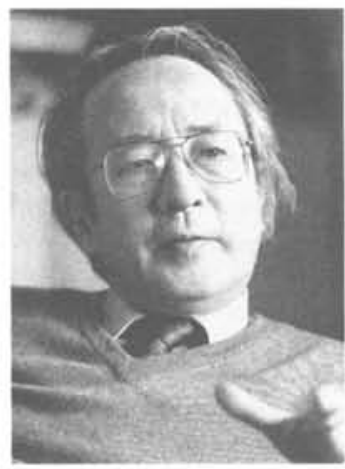

Dr. Seiya Uyeda was born in 1929 in Tokyo. From 1969 to 1990 he was Professor in Geophysics at Earthquake Research Institute, University of Tokyo. Currently, he is Professor in Geophysics at Texas A\&M Univer. sity, College Station, Texas, USA, and at Tokai University, Shimizu, Japan. He is a foreign associate of the U.S. National Academy of Sciences; a foreign Honorary Member of the American Academy of Arts and Sciences, the European Union of Geosciences, and the Societé Geologique de France: and a Fellow of the American Geophysical Union, the Geological Society of London, and the American Association for the Advancement of Science. He is Editor-in-Chief of Tectonophysics and a Vice President of IUGS. Dr. Uyeda is interested in rock magnetism, marine and land heat flow, earthquake prediction, tectonics of island arcs, and plate tectonics. 